\title{
OBITUARIES
}

\section{PANDIT NeHrU}

This Society mourns with India the passing of one of its greatest sons and one of the world's great men, Pandit Jawaharlal Nehru.

Born a Kashmiri Brahman he was the son of an eminent lawyer, Pandit Motilal Nehru, leader of the bar in Allahabad, whose children had the cosmopolitan education of conversation in Urdu and Persian and of lessons in English and French. From his father Pandit Nehru inherited not only a distinguished personality and kindly nature but a brilliant intellect. When he grew up he was sent to Cambridge where he acquired an ineradicable liking for England in spite of the years of detention to which his political activities condemned him before his country became independent. A visitor once asked Lord Wavell if Pandit Nehru was bitter over those fourteen years. "Not half as bitter as I would be", replied the Viceroy. Nehru in fact was without rancour and those years left no mark on his handsome features and never extinguished his sense of humour. An Englishman once regretted to him in London that he had failed to meet him in Delhi because he had contracted foodpoisoning. "What! food-poisoning at Viceregal Lodge", Pandit Nehru replied, his face beaming with amusement.

This brief tribute can do no more than allude to Nehru's devotion to Gandhi, to Gandhi's choice of him as his successor, to Nehru's long years of political struggle when as early as 1929 he envisaged India's complete independence and to the statesmanship which changed that policy into independence within the Commonwealth. It is for the historian to study all the facets of his career as agitator, politician and statesman. But whatever the historian's outlook may be, it is certain that he will find Pandit Nehru "nothing common did or mean" on the stage of this world which he adorned so selflessly and so brilliantly.

\section{DR. A. A. BAKE}

Dr. A. A. Bake, Reader in Sanskrit in the University of London, died on 6th October, 1963, at the age of 64, courageous and genial to the end.

Born in Hilversum he was first educated there and at Haarlem, afterwards studying Sanskrit at Leiden and finally at Utrecht, which 
awarded him the degree of Doctor of Letters for his study of an early Indian musical text, The Mirror of Music (1930). 1925-29 he had spent in India, working at Santiniketan under Rabindranath Tagore where he came to love India and its music. He was also able to visit Nepal and study there.

After four years of research at the Kern Institute in Leiden, he was awarded a Spalding Research Fellowship (1937-44) at Brasenose College, Oxford, when he visited India for a further study of its music, acquiring a knowledge that very few Indians could emulate. A wonderful voice allowed him to illustrate with his own singing, the lectures he gave in Europe and North America.

Settling in England, in 1948 he was appointed Reader in Sanskrit in the University of London. In 1955-6 he revisited India and in Nepal recorded much unknown material, to the classification and study of which he devoted a great part of the time left to him. He contributed important chapters to the New Oxford History of Music and to several encyclopædias.

To his widow, the Society extends its respectful sympathy.

\section{ProfesSOR EDWARD ROBERTSON}

D.LITT., D.D. (St. Andrews), HON. D.D. (Wales), LL.D. (Manchester)

Professor and Mrs. Edward Robertson, both aged about 80 had but recently left this country to live with the family of their daughter Helen (Mrs. W. H. Morton) in the province of Quebec. In February this year Mrs. Robertson suffered an accident from which she died; a few weeks later news came of Professor Robertson's passing. Both will be missed, and both will be remembered in countless ways, for they were amazing people. They had become legendary figures of whom it was said: "What next!" Yet never has anything been said or even thought of them except in admiration and with deep affection.

Professor Robertson was born in Cameron, Fife, about $1880-$ though the actual year seems never to have emerged in Who's Who. He first showed academic promise in mathematics at St. Andrews, but soon turned to Semitic Languages, which he continued to study at German Universities and in Syria. He lectured in Arabic at Edinburgh (1913-21), then he became Professor of Semitic Languages at the University College of North Wales, Bangor (1921-34) and later held the parallel Chair at Manchester University until his 